\title{
MIR34A wt Allele
}

National Cancer Institute

\section{Source}

National Cancer Institute. MIR34A wt Allele. NCI Thesaurus. Code C95832.

Human MIR34A wild-type allele is located in the vicinity of 1 p36.22 and is 110 bases in length. This allele, which encodes MIR34A pre-miRNA, plays a role in the regulation of mRNA translation. 